\title{
War and the subaltern: Voice as power in Buchi Emecheta's Destination Biafra
}

\section{Ogbu Chukwuka Nwachukwu, Oyeh O. Ołu \& Onyekachi Eni}

\section{War and the subaltern: Voice as power in Buchi Emecheta's Destination Biafra}

In Africa, as in most other parts of the world, whenever there is war (or massive violence of any other hue), the common people are used as cannon fodder to protect the powerful upper class formulators of the letters of the war. Women and children are easily the most vulnerable. They are raped, tortured, murdered, starved, widowed, and exposed to all sorts of insecurity and depredation. In the end they are marginally characterized in upper class, male-centered war discourse. In this research, we locate the voice of the subaltern in Buchi Emecheta's civil war novel, Destination Biafra (1982). We utilize Subaltern Studies in a qualitative approach to offer the needed agency to female subalterns as well as a few other marginalized groups. We map the trajectory of these voices and show that the subaltern woman and the other margins denounce colonial complicity in the androcentric war, and would rather the society eschewed violence as conflict resolution strategy. With this study we fill an existing gulf in the Nigerian Civil War narrative and create an alternative discourse against the largely upper class, male-centered voices that have hitherto characterized civil war novels. Keywords: war, subaltern, voice, power, Nigerian civil war, androcentrism, Subaltern Studies, postcolonial criticism.

\section{Introduction}

Some schools of thought see war as a struggle to gain or retain power. They claim that it may be a violent conflict necessitated by the need to force an adversary to obey one's will. They insist that, to achieve this objective, the warrior must subject his opponent to a condition that is clearly worse than the sacrifice of surrendering his liberty. They note that war does not take place between individuals but between states or between a nation and a state, often as a result of the necessity for violence where conversation or constructive engagement has failed (Von Clausewitz 2; Rousseau 8-9; Long 1). As Jean-Jacques Rousseau observes, states can only have other states as enemies since "between things disparate in nature, there can be no real relation" (9). This presupposes that individuals within warring states may be only accidental enemies.

Despite this presupposition, individual men and women may be enemies only in relation to a state or a nation as war affects people on individual level. Incidentally, while members of the upper echelons of society often engage in actions that precipitate war, it is the people at the margins of society that often suffer the consequences of warfare the heaviest. This segment may be the main victims of war based on their gender, class, race, ethnic origin, religion, or even ideology vis-a-vis the interest of neo-imperialism/cosmopolitanism. Whereas they are often the cannon fodder for the prosecution of war by virtually all belligerents, the poor and the weak are, nevertheless,

Ogbu Chukwuka Nwachukwu is a lecturer in the Department of English and Literary Studies, Faculty of Humanities, Alex-Ekwueme Federal University in Ndufu-Alike, Nigeria.

Email: chukwukanwachukwu158@gmail.com

(D) https://orcid.org/0000-0003-3757-6655

Oyeh 0. Otu teaches in the Department of English Studies, Faculty of Humanities, University of Port Harcourt, Port Harcourt, Nigeria.

Email: oyehotu@gmail.com

(iD https://orcid.org/0000-0003-3210-2039

Onyekachi Eni currently serves as a senior academic with the Department of English and Literary Studies, Faculty of Humanities, Alex Ekwueme Federal University in Ndufu-Alike, Nigeria.

Email: onyekachieni@gmail.com

(D) https://orcid.org/0000-0003-3996-9268

D0l: https://doi.org/10.17159/tl.v58i2.8598

DATES:

Submitted: 4 July 2020; Accepted: 29 April 2021; Published: 18 October 2021 
hardly the ones to write the story of the war. Most often, the elites do. And each time the elites write, they implicate the subalterns in their story and subsume the voice of the poor and the weak within the framework of an upper-class narrative.

In Korea, for instance, the plight and voice of former 'comfort women' (sex slaves) both during WWII and the Korean War were systematically muffled by the Korean establishment and never known outside Korea until the late 1990s. It was the publication of Katharine H. S. Moon's Sex Among the Allies (1997) and Sangemie Choi Schellstede and Soon Mi Yu's Comfort Women Speak (2000) that exposed this war atrocity against women to the outside world. As Tae Yun Lim and Shin Haeng Lee have observed, these subaltern women were often rendered silent by "oppressive ideological mechanisms such as Japanese imperialism and patriarchal/anti-colonialist discourses in Korea that often frustrate victimized women's attempts to speak out" (5-6).

Regarding the literary output on the Nigerian Civil War, Marie Umeh, Craig McLuckie, Oike Machiko, Abioseh Porter, and Francois Ugochukwu, amongst others, decry the initial lack of focus on the female condition and participation in the war. They take umbrage at writers like Chukwuemeka Ike, Isidore Okpewho, Cyprian Ekwensi, Elechi Amadi, Eddie Iroh, I. N. C. Aniebo, and Ken Saro-Wiwa-all male. In Sunset at Dawn (1976), The Last Duty (1976), Survive the Peace and Divided, We Stand (1976, 1980), Sunset in Biafra (1970), The Siren in the Night (1984), The Anonymity of Sacrifice (1974), and Sozaboy (1990), these writers give agency to male characters in their narratives which focus on what they consider active engagement and heroism. Women, children, soldiers of low rank, and other marginalized groups are denied agency and silenced.

Festus Iyayi captures this concern in the novel Heroes (1986). In a dialogue with Osime Iyere, the hero of the novel, Sergeant Kesh-Kesh, a subaltern soldier, entreats Iyere to help write the story of the lowly soldiers because: After this war many generals will write their accounts in which they will attempt to show that they were the heroes of this war, that it was their grand strategies that won the war. They will tell the world that they single-handedly fought and won the war. The names of soldiers like Otun, Emmanuel, Ikeshi, and Yemi will never be mentioned. The soldiers take the death and the ambushes and the bullets with their lives. The soldiers pay for the unity of this country with their lives and yet, what happens? Always the officers are the heroes. Always the generals, the officers take the credit. Always the generals get the praise. Always they are the heroes. Always. (86)

Thus, the margins and some other thorny issues resulting from the war are glossed over in what Chimalum Nwankwo has described as "literary exercises better fitted to the full-belly faddish reflections of blasé coteries" (1).

Yet, most of the Nigerian Civil War scholars agree that the war has elicited so much literary focus that it has surpassed all other subjects, including colonialism (Nwachukwu-Agbada 104; Nwuga 194). This is not surprising at all. War is a subject of interest given the pain, depredation, and anguish that it evokes. In Half of a Yellow Sun, Chimamanda Ngozi Adichie states that the events of the war necessitate recall so that we may never forget (207, emphasis added). As a corollary, the Russian writer Yuri Bondarev claims: "I write about it (WWII) not only because war is the most painful ordeal for humanity but also because it is exceedingly important for me to see my character in the most difficult and dramatic situations where moral values are tested to the utmost" (197).

In this study we focus on the depiction of the Nigerian Civil War in relation to the super-ordinates of war and the subaltern classes in Buchi Emecheta's Destination Biafra (1982). It is important to x-ray the import of war to both the elite and the subaltern so as to capture the class that is the most marginalized and faced with the greatest security challenge. The work will trace the path and the voice of the subaltern in the dangerous, life threatening incidence of war in Africa-Nigeria in particular. It is necessary to find the voice of the lower/oppressed classes amid a cacophony of oppressive and master voices so as to situate it as a central concern and provide a credible alternative discourse around the war along gendered and group interest lines. The study appropriates Subaltern Studies to investigate power relations in the cause of the war between the subaltern victims and the elite centers of power.

As "an attempt to allow the people to speak within the pages of elitist historiography", Subaltern Studies enables the marginalized to "speak for, or to sound the muted voices of the truly oppressed" (Mambrol). Women, peasants, workers, and other groups who have no access to hegemonic power constitute the bastion of subaltern classes. The word "subaltern" is a term for the general attributes of subordination in terms of gender, race, class, ethnicity, etc. Ordinarily, the term refers to "an officer in the British army below the rank of a captain"; and as an adjective it means "of lower status", or "of inferior quality". It entered the English lexicon in the $16^{\text {th }}$ century from 
its etymological late Latin subalternus which means "inferior in rank", or "secondary importance" (Dharmaraj 26). Subalternus itself is a combination of the Latin sub, 'next below', and alternus, 'every other'.

The Italian Marxist, Antonio Francesco Gramsci, was the first to deploy the term to denote the working class people in Italy and to delimit their history as consequent upon the history of the state; that is, the upper class. He claimed that this will remain so until the subalterns "are able to become a "state" (202). Gramsci pinpointed the connotation of the unrelenting oppression and exploitation of the rural peasantry in Southern Italy in terms of gender, class, caste, race, and culture and proceeded to outline six enabling presumptions for the study of the history of subaltern classes in "Notes on the Italian History" (202-3). Gramsci's deployment of the term formulates a Eurocentric method of historical investigation of the non-Western peoples of Africa, Asia, and the Middle East in their relation to Western Europe as logo-centric of world history (Prakash 1476). Prakash explains that Eurocentricity in this vein suggests the historicism "that projected Europe as history" (1476).

Subaltern Studies became a branch of postcolonial criticism and gained momentum from 1982 through the efforts of the South Asian Subaltern Studies Group (SSG) - the Subaltern Studies Collective-most outstanding among who are Ranajit Guha and Gayatri Chakravorty Spivak. Other influential voices include Chakrabarty Dipesh, Gyan Prakash, Partha Chatterjee, Sudipta Kaviraj, and Sussie Tharu. India's historic-cultural environment and her colonial experience offer fertile grounds for the propagation and espousal of Subaltern Studies. The Hindu caste system and cultural practices such as dalit, or untouchables; scheduled tribes; sati, or widow immolation; and others, are fertile for the subaltern discourse not only in literary studies but also in history, sociology, anthropology, and psychology. Guha states that the aim of Subaltern Studies was to "rectify the elitist bias characteristic of much research and academic work" in South Asian Studies ("On Some Aspects of the Historiography of Colonial India" vii). He explains that this act of rectification was necessary because the elites had exercised dominance, not hegemony, over the subalterns. To him, the subalterns had acted in history on their own, that is, independently of the elites; so, their politics constituted "an autonomous domain, for it neither originated from elite politics nor did its existence depend on the latter" (3-4).

Gayatri Spivak pinpoints the heterogeneity of subalternity and proceeds to expand the group to include muted women, colonized people, oppressed generations, working classes, minority tribes, and black people ("Can the Subaltern Speak?" 276). In "The Trajectory of the Subaltern in my Work", Spivak asserts that subalternity is a position without identity, that the word 'subaltern' and the idea of the popular "do not inhabit a continuous space at all", and that the relationship between the subaltern and the popular is similar to that between class and poverty, race and colour, or gender and sex (3). Spivak is particularly concerned that the gendered subaltern has kept moving down the social strata, lacking "access to the lines of social mobility". Subalternity, therefore, cannot be autonomous because "there is little autonomy in gender relations. It is all about the woman and her resistance not being recognized" (6).

As a postcolonial theory, subalternity is concerned with the colonial populations who are socially, politically, and geographically outside the hierarchy of power of a colony and of the empire's metropolitan homeland in describing cultural hegemony as popular history (Ludden 45). It responds to the issue of subordination and silencing of the suppressed and marginalized people in postcolonial societies. Spivak informs us that sati practice (self-immolation of widowed Hindu women), for instance, marks the limits of historical knowledge. The voice of the sati was not heard to ascertain if she willingly presented herself for immolation or not. It was impossible, therefore, to retrieve the voice of the subaltern woman when she was not given the subject position ("The Making of Americans, the Teaching of English, and the Future of Culture Studies" 35). Spivak holds that it is only when the subalterns' voice is heard that they cease to be at the margin, for they cannot be represented by their privileged oppressor ("Subaltern" 299-307). To achieve this, subalterns must have agency, become subjects, and build infrastructure ("Trajectory" 3).

As Prakash states, Subaltern Studies gains its force as Postcolonial criticism from "a catachrestic combination" of Marxism, Poststructuralism, Gramsci and Foucault, the modern West and India, archival research, and textual criticism (1490). Dipesh observes that subaltern theorists relied much on 'textual readings' due to "the absence of workers' diaries and other such sources available to British historians" (102). This lends credence to Spivak's position that "the colonized woman is caught between indigenous patriarchy and the politics of archival production" ("The Rani of Sirmur: An Essay in Reading the Archives" 247).

Significant to this study is the fact that Subaltern Studies gives voice and power to all attributes of subordination. In this study we investigate Emecheta's delineation of war in Destination Biafra, in relation to the subaltern 
classes. We engage a clear analysis and evaluation of the whole demographics of victimization and marginalization in the war such as women, Igbo, children, and even the local or native upper class in a play of power with the former colonists. We seek to establish colonial complicity in the war atrocities buoyed by selfish neo-colonial interest and to establish the rendering of the subaltern voice and the signification of restiveness in the character of the subalterns - particularly the subaltern women - which indicate their dissatisfaction in their marginalization through war.

\section{The colonial mastermind and the native upper class subaltern}

In the novel Destination Biafra, in the bid to maintain a neo-colonial stranglehold on the erstwhile colony, a retreating British colonial coterie enthrones an unpopular government in the newly independent West African state. The puppet government, led by Alhaji Nguru Kano, is mired in administrative profligacy, incompetence, corruption, nepotism, and the promotion of mediocrity. Consequently, a group of missionary soldiers execute a coup, killing most of the leaders perceived to be complicit in the mismanagement of state affairs and resources. The coup is foiled and a new military government is formed. Within a few months, a counter coup is successfully executed and another military regime is enthroned. Large-scale killing of Eastern Nigerians, particularly Igbo, follows. This leads to secession and the declaration of the Biafran Republic, led by Colonel Chijioke Abosi. Debbie Ogedemgbe joins the army from the Nigerian side and is sent to Biafra as a peace envoy. A female soldier, she is faced with dire circumstances en route to Biafra, but she is determined to succeed and to help a few other women survive the dangerous war. Debbie eventually arrives in Biafra and engages in strategic diplomacy in order to survive the belligerents. As Biafra capitulates and the war ends, Debbie resolves to narrate the war from the angle of the oppressed women, and to see to it that the Baby Biafra, most affected by the war, survives to hear the story of the war.

Emecheta implicates colonialism and neo-colonial tendentious meddling in the affairs of colonized subjects as the de facto cause of the Nigerian Civil War. She shows that the imperialists deployed political subterfuge in the post-independence control of the subaltern state in order to continue to secure the country's resources for post-imperial gains.

Prior to Nigeria's independence, Sir Macdonald, the Governor-General, had decided to determine the outcome of the forthcoming election for neo-colonial gain. Emecheta tells us that the colonists desire that "[...] any profit to come out of Nigeria should go to Britain rather than to any other country"; so, they "had to ensure that the first Prime Minister was a Hausa man, preferably the Sarduana" (Destination Biafra 15). Pursuant to this ploy, Sir Ferguson Grey had urged Mallam Nguru Kano to allow Hausa/Fulani women to vote in the forthcoming elections to which the latter retorted: "In England you had democracy for years before your women were allowed to vote? I presume this is so?" (10). This riposte signifies the colonial subject's voice of revolt and implies the rescission of colonial order. This notwithstanding, Sir Ferguson Grey engages his son Allan Grey, a colonial commander in the then Nigerian Queen's Own Regiment, to investigate the possible outcome of the impending elections so that, if it should tilt against British interests, some action would be taken.

Macdonald is aware that Dr. Ozimba is the people's favourite candidate, but he thinks that Ozimba and his Igbo kinsmen are too intelligent, too inventive and industrious, and too ambitious to accommodate neo-colonial interests. Similarly, Chief Odumosu and his political party, AG, with his Yoruba supporters, are considered too sophisticated and too much of administrators and economy managers for their African environment. Macdonald, therefore, proceeds to secure the army for the purpose of quelling the anticipated uprising. He tells Allan Grey, "Whatever you do, Grey, keep the army on the alert. I may need them to keep the peace" (16).

As part of the grand design to rig the election, Macdonald waits for "only forty results out of a hundred and ninety from the North" (22) to be declared before he calls, appoints, and congratulates Alhaji Nguru Kano as the new Prime Minister. To consolidate this, he drafts in soldiers to surround Ozimba's residence. The soldiers are to arrest or shoot Ozimba down if he tries to organize a protest with his numerous supporters who are dissatisfied with the outcome of the elections. This action spells trouble for the young republic. Even though Ozimba takes a stoic posture on the glaring imposition of the wrong candidate on the people, some others do not. His assistant, Dr. Eze "felt like crying for this man who had done so much for Nigeria: the imprisonment, self-denial, and the sleepless nights of planning speech after speech - all for nothing". Mrs. Ozimba, in a fit of rage, shouts, "But this is unfair. What have the Hausas done for Nigeria? They sat there in the North while we the Ibos (sic) did everything [...] I can see no peace in this country with this kind of treachery" (22). But the crux of the matter is that 
the retreating colonist does not want the native who had done so much, who seemed to know what to do, and who is capable of raising a voice to effectively reclaim the vassal nation from intended neo-colonial stranglehold. As Ozimba stoically declares, "we are dealing with a power stronger than we are" (23).

Ozimba is popular and truly loved by the people, including members of the armed forces. Colonel John Nwokolo declines the colonist's order to assassinate Ozimba. Saka Momoh, also a colonel, is dissatisfied with the outcome of the election. In a show of solidarity with Ozimba, the popular and true winner of the election, Momoh complains to Nwokolo: "They call this an election? Pooh!" To which Nwokolo retorts: "It is not an election but a time bomb. It will explode soon, you mark my words. How many of us are going to sit on our backsides and watch this happen? Mallam Nguru Kano the first Prime Minister indeed! This result is like playing Hamlet without the Prince. Can you imagine a Nigerian Government without the great Ozimba? (25)

This is the stage set for the country's independence by the retreating colonial mastermind serving his supervening interest over others'. Spivak has expressed doubts that the voice of the subaltern may ever be recovered given the "unimaginable extent of colonial repression and its historical intersection with patriarchy [...]" ("Subaltern" 275). The polity created by the disengaging colonists is adventitious and they desire that it remain so. This naturally leads to a scramble for power, ethnicity, kleptomania, political rivalry, flamboyance, and more social malaise. Then, disillusion follows the formative years of independence, leading inevitably to a military coup, a counter coup, and sustained violent suppression of the people of the Eastern region, particularly the 'Ibo' (Igbo), culminating in Chijioke Abosi's secession and Saka Momoh's declaration of war against the 'rebels'.

\section{A dangerous mission, war's victims, and the voice of the subaltern}

Debbie Ogedemgbe is a University of Oxford graduate and the daughter of a slain high profile, but thoroughly corrupt, erstwhile finance minister. She joins the army "to help the Nigerian Army, not as a cook or a nurse, but as a true officer!" (Destination Biafra 45). Debbie, female, is aware of the hurdles in the combat section of the army, a male-dominated site. Yet, she is determined to shed the subaltern status foisted on females through hegemonic constructions. She is well educated, and of the upper social class. She holds the view, therefore, that "if intelligent people and graduates were beginning to join the ranks of the Nigerian Queen's Own Regiment, she intended to be one of them" (45). However, Debbie's intention to enlist in the army is treated with suspicion and levity. She is eventually enlisted for convenience: to exploit her sexuality, and the verdict is, "well, if she can be a useful tool, I don't see why we should not use her and others like her" (69, emphasis added).

Aware that she is meddling in a hitherto male-dominated site, Debbie "obeys the masculine rules of war and politics and tries to be more manly than the men" (Machiko 63). This is demonstrated in her first major assignment which is to arrest some Igbo officers in the Ikeja military barracks. Here, she shouts her orders "at the top of her voice" and this causes "the sinew of her thin neck to bulge" (Destination Biafra 79). This strident hollering is an attempt to emphasize the need for her voice to be heard and reckoned with in a patriarchal domain. Debbie's effort is in line with the Spivakian assertion that if the subalterns speak and their voice is heard, they have agency and cease to be at the margin (Dharmaraj 36). The contemptuous amusement on the faces of the arrested Igbo officers seem to taunt Debbie with, "whatever you do, remember that you are a (mere) woman" (Machiko 63). In any case, when Debbie realizes the true import of the arrest that she was sent to effect, she refuses to carry out the assignment because she does not want to continue to aid men in their macho atrocities. Instead, she elects to embark on a dangerous journey to Biafra as a peace envoy. Here again, what is useful to the masculine high command is her sexuality. She is told, "Don't forget, my dear, that you are a woman. That is why we are giving you this delicate mission" (Destination Biafra 129). She is enjoined to utilize her sexuality to entice and destroy Chijioke Abosi, the arch rebel. Otherwise, she is warned not to "meddle in things that are bigger than (her)" (129).

Debbie embarks on the journey, code-named Destination Biafra, having been assigned the stereotypical role of a whore and a peacemaker. In the course of this duty, she is raped twice by Nigerian soldiers, who are supposedly her colleagues-first by Bale and company, next by Lawal. Of significance here is the fact that this society has different codes of morality for the male rapist and for the female rape victim. The male rapist is not stigmatized while the female rape victim is seen as unclean, a social deviant, and treated with disdain. Thus, Igwedibia and Yerima implicate society as well as combatant soldiers as a source of serious threat to the female at war (276). Rape is both a psychological weapon and an act of oppression by the strong over the weak. It is often an androcen- 
tric weapon that tyrannizes the female (Riberio 21). Georgiads Mboya Kivai also captures the incidence of rape quite succinctly when she avers that:

Rape is an expression of power and authority. It is a form of violence and most of the perpetrators are men. Men desire to rape women in order to assert authority over them. Rape can even be a symptom of inequality and a desire on the part of those who wield power to assert it over the powerless [...]. It is an action rooted in masculine behaviour that serves to perpetuate masculine order. (87)

Debbie is treated with scorn and derision by various rapists, especially because she dared to enlist in the army and actually wears her ill-fitting baggy trousers in the name of a soldier. As her mother observes, Debbie's problem is that, "born a girl, (she) wants to be like a man, and wants the men to know that she wants to be like them, and still wants to retain her womanhood" (Destination Biafra 161). Thus, Lawal excoriates and rapes her not only because she is Europeanized and consorts with European men but, importantly, for also challenging the androcentric status quo ante by daring to join the army, a site that is supposedly exclusive to powerful men. Lawal threatens, "I am going to show you that you are a woman, an ordinary woman" (175). From this prismatic point, we see that Lawal uses rape to coerce Debbie in what Kivai describes as "an expression of power and authority" (87). There is also a psychological dimension to Lawal's attempt to rape her. If he had succeeded, he would have exercised power over Debbie's neo-imperialist boyfriend, Alan Grey, to assert superiority over the former colonizer at a symbolic level, at least in his thinking. Lawal fails to achieve coital catharsis with Debbie. However, he sublimates his failure with the claim that it is deleterious to have sex with a woman who consorts with such an immoral European as Alan Grey. Debbie's victory over her traducer is a victory for the subaltern female. She pities Lawal by offering to sleep in his bunk till daybreak to massage the latter's ego. She taunts him with, "You poor, poor men have so many problems to solve, problems you created for yourselves" (Destination Biafra 177).

At this second scene of rape, the women are made to watch their husbands get shot. Worse still, these women carry the burden of protecting and caring for their children without their husbands. The pregnant mother of Baby Biafra runs hysterically at the killer of her husband, asking him "what she was supposed to do with the child she was carrying" (186). Debbie tactically refuses to resist rape. Her visionary and missionary motives are to bond with Uzoma Madako, Dorothy, and the rest of the women in order to lead them with their children to safety, write their version of the war story, and offer an alternative voice to the dominant hegemonic narratives. Mrs. Madako resolves to survive in spite of the brutal murder of her husband, stating: "Our husbands were useful, yes, very useful; but they have now been killed by other men. We have children to look after. Just like our grandmothers looked after our parents who had us" (213). This confirms Ibekwe Chinweizu's view that, rather than weak, the African woman can be very strong (85-6). Lauren Rackley has also noted that, in dire circumstances, females can cross so-called gender lines "[...] in order to protect themselves and their families" (6).

Destination Biafra narrates women's war. It is their war to survive male onslaught, both literally and metaphorically. Fleeing Biafran soldiers commandeer women for their pleasure and conscript men for war. Advancing federal troops kill men, rape women, and leave them to cater for children whose fathers they had killed. They plunder the land and steal cattle, goats, and chicken. Debbie's wilful entry into a career considered to be men's exclusive preserve questions the Aristotelian view that "woman may be said to be an inferior being" (Kaplan and Anderson 31). In fact, her bravery is a frontal challenge to the claim that "valour in a woman or, unscrupulous cleverness is inappropriate" (31). Debbie's personality and activity vindicate Judith Butler's position that "[...] gender is not a fact, the various acts of gender create the idea of gender, and without those acts, there would be no gender at all" (273). Her initial inhuman treatment in the hands of Nigerian male soldiers is enough warning as to the dangerous nature of her journey to Biafra. Yet, rather than being deterred, she grows even more resolute to carry out her assignment. Her decision to wade through the jungles of the mid-west alongside Uzoma Madako, Dorothy, the Nwoba boys, Ngbechi, and others, places her at par with the other subalterns. In fact, her activism is comparable to the activism of Muthoni Likimani with the Kenyan Mau-Mau (James 60-1). Perhaps she is inspired by Christina de Aragon of the Spanish army fame. Perhaps she takes a cue from the Dahomey Amazons who made the days of the Abeokuta male warriors nightmarish (Johnson 106-9).

As a group, the Igbo within Nigeria's territory are made cannon fodder of the war. Lawal deceives them in Benin to "Gwo, gwo, gwo to your Biafra and eat yam. Leave Nigeria where we have given you English bread, gwo there and eat your Abakaliki yams and cocoyams" (Destination Biafra 168). Ironically, the same Lawal waylays and massacres them in the bushes of the Mid-West. When the massacre is over, more than two hundred men, many of 
whom were younger than sixteen, are killed. After the murder of these Igbo men in cold blood en route to Asaba, Lawal orders "the jeeps, trucks and ambulances to run over the bodies of more than two hundred men" (177). In addition, fifty widowed women are loaded off to their misery, but not before they are dehumanized by the soldiers:

They swaggered up to women passengers, shouting, "Are you sure that you are a woman? Are you sure? Take your clothes off. If you don't, you are a dead Ibo (sic) liar [...]" the women stripped their clothes off [...]. The soldiers were not satisfied. They now had to touch, they had to squeeze, they had to slap even probe, as the whim took them, to make sure these were really women $[\ldots] .(171)$

These women suffer double tragedy. They watch as their husbands are killed. They also live with the unfortunate fact that they have to face the war with their children but without their breadwinners. Again, children like Ngbechi, Ogo, and the two Nwoba boys are left with Debbie, Mrs. Madako, and Dorothy (who later dies) to wade through the thick jungles of the Mid-West. The subaltern victims of the war are helpless in the matter. As Lawal remarks, "this is the only way to force Abosi's hand" (176). In a moment of nostalgic anguish, five-year-old Ogo declares: "when we get to Biafra, the land will be dry, my mother will be there and my father, and my mother will cook fried plantain and chicken stew" (210). This is a picturesque but sad commentary on the helpless nature of the condition of the victims.

In spite of all the odds, these victimized subaltern women show character and strength. Although Lawal attempts to rape her, Debbie defeats him as her frigidity denies him sexual steam. Then she beats him with a slap and Lawal falls back on the bed. This symbolizes the triumph of the subaltern woman over masculine hegemonic symbols of terror and subjugation. Stella Ogedemgbe is resilient. She absorbs her personal humiliation at the rape scene. In spite of her humiliation, she pleads, "Do whatever you want with me, and afterwards kill me. But [...] leave my daughter out of it. Don't let me see my daughter humiliated" (133). When this plea falls on deaf ears, she rallies, maintains equanimity, and comforts her traumatized daughter. Uzoma Madako is resilient and industrious. Like Stella Ogedemgbe, she has the survival impulse. The mother to the Nwoba boys is self-sacrificing. She allows her two boys to move on with Debbie with a higher possibility of securing their lives than they would have if they tagged along with her, in which case they would probably end up dead, like their father. This shows the resilience and humanity of the female subaltern. She desires for the human race to survive and live in peace. This is in contradistinction with the animalistic tendencies of the male soldiers and their commanders. Through the selection of events and characterization, Emecheta is able to highlight the impact of war on the lowly, notably women; poor Biafran men; and children.

As noted from the outset, the neo-colonists portrayed in the work such as Sir Ferguson Grey, Alan Grey, MacDonald, etc. come with greed, insincerity, exploitative tendencies, and cultural emasculation of the African people. Alan Grey is planted in the Nigerian army just for that purpose. During the war his itinerary as a collector of artifacts and as military expert is a front, a subterfuge to protect British interest and profit. He is two-faced and engages in double game. Grey encourages Momoh to embark on total war against Biafra. The motive for this advice is to create an atmosphere conducive to neo-imperial economic gains. Total war means the deployment of massive and sophisticated war machinery which the British would supply at exorbitant rates. Momoh is to concession lots of oil blocks to the British as payment for the military hardware. To this extent, the native (emphasis added) elite involved in the war are treated as subalterns by the superiority-feigning neo-colonists. First, the African leaders are incited to start a fratricidal conflict through robust propaganda and political subterfuge, then they are cajoled to sign strangulating economic pacts.

Alan Grey is ready to be insulted by Momoh "as long as British investment interests were safeguarded". He reminds Momoh to "[...] sign percentages of the oil revenue over to people who would help win the war. [...] The best combat would be heavy and quick" (152-3). As could be expected, Alan Grey, the neo-imperialist, comes with a bag of tricks feinting towards Momoh's welfare but cashing in on the man's idiocy to rake in a good harvest for the undying acquisitive appetite of Sir Ferguson Grey and other neo-colonial British hawks. This is even reflected in his love affair with Debbie. He merely patronizes her when he discovers that she had been raped: "I'll marry you if that is what you want" (159). Debbie, on her part, rejects this half-hearted marriage proposal which symbolizes neo-colonialism: "I am a woman and a woman of Africa. I am a daughter of Nigeria and if she is in shame, I shall stay and mourn with her in shame [...] I am not ready yet to become the wife of an exploiter of my nation" (258). She is fully aware that British interest in Africa is as insincere as Alan Grey's marriage proposal. Her rejection of the proposal is symbolic of her rejection of neo-imperialist influence on African affairs. Instead, 
Debbie elects to do humanitarian work by saving orphaned Biafran children like the Nwoba boys with her share of her father's money. She is equally determined to "tell those orphans the story of how a few ambitious soldiers from SandHurst tried to make their dreams a reality" (258, emphasis added). This is in consonance with Guha's quest to recover the peasant from the elite (Elementary Aspects of Peasant Insurgency in Colonial India iv).

But then, it seems difficult to recover the subaltern's voice given that "[...] subalternity signified the impossibility of autonomy" (Prakash, 1490). Again, as Veena Das ruminates, subaltern rebellions offer only fleeting moments of defiance, "a night-time of love, not a life-time of love" (315). Nevertheless, Partha Chatterjee relieves the preceding concern when he states:

[...] in a sense, the subaltern can be made to speak, but made to speak by someone else who interprets their speech on their behalf. Once that kind of interpretation has been given, the interpretation itself is subject to other interpretations. Therefore it becomes open to a wide field of interpretations and representations. Once that happens you can say that the subaltern has become legible (audible too). (Chatterjee and McGrail 2-3)

It stands to reason, then, that Debbie is qualified and suitable to represent the subaltern classes and tell their story from their angle. She is of the elite class, and is a member of the ruling class grappling with the veils of inferiority cast on them by the retreating colonist. She is also a woman, a gender class that "lacked access to lines of social mobility" (Spivak, "Trajectory" 2). The abuses and injustices that she and the other women suffer are symptomatic of the subjugation and inferiorization of women in patriarchal cultures. Debbie, therefore, bonds with Uzoma Madako. Both women resolve to survive to raise future Biafrans and to use their own voice to represent the reality of the war from the subaltern angle, the angle of the most oppressed segment of the male-induced war.

\section{Conclusion}

We have investigated how Emecheta locates the voice of the subaltern in her Nigerian Civil War novel Destination Biafra. The location of the subaltern voice serves to offer power to the hitherto powerless sections of the war narratives. With the aid of subalternity as a strand of postcolonial theory of the oppressed, we argue that the scheming to gain, retain, and control power in Africa by the retreating colonist was patently selfish and led inexorably to a civil war in Nigeria. We show that, although the subaltern is most adversely affected by the war, (s)he is normally denied a voice when the story of the war is told. Consequently, we show that Emecheta's Destination Biafra convincingly situates the voice of the subaltern woman-and other marginalized groups such as the Igbo and children - within the literary framework of the Nigerian Civil War. This is significant because it fills an existing gulf in civil war narratives. Besides, it creates an alternative discourse against the earlier, largely upper class, androcentric voices that characterized civil war fiction. Emecheta's frontal challenge to male-centred discourse on the war played a pioneering role in locating, rescuing, and situating the voice of the female shifted to the margins of narration by the dominant elitist patriarchal tribe of formative writers on the subject. Emecheta, therefore, gave verve and voice to more female writers like Chimamanda Ngozi Adichie, Sefi Attah, Akachi Ezeigbo, and Dul Johnson who capture changing gender roles, explore the home front, and offer agency to the female subaltern engaged in the war.

We have demonstrated that this study offers a fresh dimension to the reading of the marginalization of women and other minority groups in the Nigerian Civil war. We have shown that it centralizes the voice of the 'other', the voiceless, or the muted voices of the carnage that was the Nigerian Civil War. The research is equally important because it offers a West African variety of Subaltern Studies other than the traditional South Asian studies of a similar nature focused on dalit, sati, scheduled tribes, and the rest of Indian peasantry. 


\section{Works Cited}

Adichie, Chimamanda N. Half of a Yellow Sun. Farafina, 2006.

Bondarev, Yuri. "Why Do We Write About the War? Do the Russians want War?" Literaturna Gazeta 1975, p. 197.

Butler, Judith. "Performative Acts and Gender Constitution: An Essay in Phenomenology and Feminist Theory." Theatre Journal vol. 40, no. 4, 1988, pp. 519-31. http://www.jstor.org/stable/3207893.

Chakrabarty, Dipesh. "Trafficking in History and Theory: Subaltern Studies.” Beyond the Disciplines: The New Humanities, edited by K. K. Ruthven. Australian Academy of the Humanities, 1992, p. 102.

Chatterjee, Partha \& Richard McGrail. "Subaltern Studies: A Conversation with Partha Chatterjee." Cultural Anthropology. n. d. https://journal.culanth.org/index.php/ca/subaltern-studies-partha-chatterjee.

Chinweizu, Ibekwe. Anatomy of Female Power. Pero, 1990.

Riberio, Célia Margarida Da Silva. "Representations of Rape in Selected Fiction by African Women." MA Thesis. U of Aveiro, 2005.

Das, Veena. "Subaltern as Perspective." Subaltern Studies 6: Writings on South Asian History and Society, edited by Ranajit Guha. Oxford U P, 1994.

Dharmaraj, M. "Indian Writing in English: Subaltern Literary Concept-Oppression of Untouchables in Rohinton Mistry's A Fine Balance." International Journal on English Language and Literature, vol. 2, no. 1, 1994, pp. 36-8

Emecheta, Buchi. Destination Biafra. Heinemann, 1994.

Gramsci, Antonio F. "Notes on Italian History." Selections from the Prison Notebooks of Antonio Gramsci, edited and translated by Quentin Hoare \& Geoffrey N. Smith. Elec, 1999, pp. 202-64.

Guha, Ranajit. Elementary Aspects of Peasant Insurgency in Colonial India. Oxford U P, 1983. DOI: https://doi.org/10.1086/ ahr/90.2.474-a.

. "On Some Aspects of the Historiography of Colonial India." Selected Subaltern Studies, edited by Ranajit Guha and Gayatri C. Spivak. Oxford U P, 1982, pp. 37-43.

Igwedibia, Adaoma \& Dina Yerima. "Women and Children at the Crossroads of War and Violence in Cyprian Ekwensi's Survive the Peace." Ikenga: International Journal of Institute of African Studies vol. 18, no. 1, 2018, pp. 272-8.

Iyayi, Festus. Heroes, Longman, 1986.

James, Adeola. In Their Own Voices: African Women Writers Talk. Heinemann, 1990.

Johnson, Samuel. "Assault on Abeokuta, City of the Egbas." Two Centuries of African English; a survey and anthology of non-fictional English prose by African writers since 1769, edited by Lalage J. Bown. Heinemann, 1981, pp. 106-9.

Kaplan, Charles \& William Davis Anderson, eds. Criticism: Major Statements. $4^{\text {th }}$ ed. Bedford St. Martin's, 2000

Kivai, Georgiards Mboya. "The Female Voice and the Future of Gender Relationships in the Nigerian Nation in Chimamanda Adichie's Purple Hibiscus and Half of a Yellow Sun." M. A. Thesis. Kenyatta U, 2014.

Lim, Tae Yun \& Shin Haeng Lee. "The Stories That Have Not Been Told: Comfort Women, Nora Okja Keller's Novels and the Subaltern's Performance of History." Concentric: Literary and Cultural Studies vol. 45, no. 2, 2019, pp. 3-26 .

Long, Jill. "What is war? A New Point of View." Small Wars Journal, 2012. https://smallwarsjournal.com/jrnl/art/what-is-wara-new-point-of-view.

Ludden, David, ed. Reading Subaltern Studies: Critical History, Contested Meaning and the Globalization of South Asia. Permanent Black, 2002.

Machiko, Oike. "Becoming a Feminist Writer: Representations of the Subaltern in Buchi Emecheta's Destination Biafra." ALT 26 War in African Literature Today, edited by Ernest N. Emenyonu. Heinemann, 2008, pp. 60-70.

Mambrol, Nasrullah. “Key Theories of Gayatri Spivak." Literary Theory and Criticism. 7 Apr. 2017. https://literariness. org/2017/04/07/key-theories-of-gayatri-spivak/.

Nwachukwu-Agbada, J. O. J. "Songs from Thunder: Nigerian War Poetry." A Harvest from Tragedy: Critical Perspectives on Nigerian Civil War Literature (revised and enlarged edition), edited by Chinyere Nwahunanya. Springfield, 2011.

Nwankwo, Chimalum. "The Muted Index of War in African Literature and Society." War in African Literature Today, edited by Ernest Emenyonu. Heinemann, 2008, pp. 1-14.

Nwuga, Charity O. "Part Nigerians, Part Biafrans: Double Consciousness and the Tragedy of Biafra in Chinua Achebe's There was a Country." Ikenga: International Journal of Institute of African Studies vol. 18, no. 1, 2018, pp. 194-204.

Prakash, Gyan. "Subaltern Studies as Postcolonial Criticism." The American Historical Review vol. 99, no. 5, 1994, pp. 1475-90. DOI: https://doi.org/10.2307/2168385.

Rackley, Lauren, E. "Gender Trauma and Orality in Adichie's Half of a Yellow Sun and Purple Hibiscus." MA Thesis, U of Mississippi, Sally McDonnell Barksdale Honors College, 2015.

Rousseau, Jean-Jacques. The Social Contract. The Great Books Foundation, Set Three, Volume Five, n. d.

Spivak, Gayatri C. "Can the Subaltern Speak?" Marxism and Interpretation of Culture, edited by Cary Nelson \& Lawrence Grossberg. U of Illinois P, 1988, pp. 271-313. DOI: https://doi.org/10.1007/978-3-658-13213-2 84.

. "The Making of Americans, the Teaching of English, and the Future of Culture Studies." New Literary History vol. 21, no. 4, 1990, p. 781-798.. DOI: https://doi.org/10.2307/469185.

"The Rani of Sirmur: An Essay in Reading the Archives." History and Theory vol. 24, no. 3, 1985, pp. 247-72. DOI: https:// doi.org/10.2307/2505169.

."The Trajectory of the Subaltern in my Work." UCTV. 13 Sep. 2004. https://www.uctv.tv/shows/Gayatri-Spivak-TheTrajectory-of-the-Subaltern-in-My-Work-8840.

Von Clausewitz, Clemensartz. On War, edited and translated by Michael Howard \& Peter Paret. Princeton U P, 1984. 